\title{
Enforced Marginality
}


THE S. MARK TAPER FOUNDATION

IMPRINT IN JEWISH STUDIES

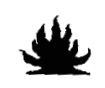

BY THIS ENDOWMENT

THE S. MARK TAPER FOUNDATION SUPPORTS

THE APPRECIATION AND UNDERSTANDING

OF THE RICHNESS AND DIVERSITY OF

JEWISH LIFE AND CULTURE 


\section{Enforced Marginality}

Jewish Narratives on Abandoned Wives

\section{Bluma Goldstein}

甲

UNIVERSITY OF CALIFORNIA PRESS

Berkeley / Los Angeles / London 
University of California Press, one of the most distinguished university presses in the United States, enriches lives around the world by advancing scholarship in the humanities, social sciences, and natural sciences. Its activities are supported by the UC Press Foundation and by philanthropic contributions from individuals and institutions. For more information, visit www.ucpress.edu.

\section{University of California Press}

Berkeley and Los Angeles, California

University of California Press, Ltd.

London, England

(C) 2007 by The Regents of the University of California

Library of Congress Cataloging-in-Publication Data

Goldstein, Bluma.

Enforced marginality : Jewish narratives on abandoned wives / Bluma Goldstein.

p. $\mathrm{cm}$

Includes bibliographical references and index.

ISBN 978-0-520-24968-4 (cloth : alk. paper)

I. Agunahs. 2. Jewish women-Legal status, laws, etc. 3. Jewish women in literature. 4. Jewish literature-History and criticism. I. Title.

KBM550.5G65 2007

$296.4^{\prime} 444-\mathrm{dc2} 2$

2006035371

Manufactured in the United States of America

$\begin{array}{llllllllll}\text { I6 } & \text { I5 } & \text { I4 } & \text { I3 } & \text { I2 } & \text { II } & \text { IO } & \text { O9 } & 08 & 07\end{array}$

IO $\quad \begin{array}{lllllllll}9 & 8 & 7 & 6 & 5 & 4 & 3 & 2 & \text { I }\end{array}$

This book is printed on New Leaf EcoBook 50, a 100\% recycled fiber of which $50 \%$ is de-inked post-consumer waste, processed chlorine-free. EcoBook 50 is acid-free and meets the minimum requirements of ANSI/ASTM D5634-OI (Permanence of Paper). 